\title{
Technè
}

La science au service de l'histoire de l'art et de la préservation des biens culturels

43 | 2016

Une Europe de la recherche en sciences du patrimoine

\section{De CHARISMA à IPERION CH et E-RIHS : vers une infrastructure européenne de recherche pour les sciences du patrimoine}

Isabelle Pallot-Frossard

\section{OpenEdition}

Édition électronique

URL : http://journals.openedition.org/techne/639

DOI : $10.4000 /$ techne.639

ISSN : 2534-5168

Éditeur

C2RMF

Édition imprimée

Date de publication : 1 août 2016

Pagination : 46-49

ISBN : 978-2-7118-6338-9

ISSN : $1254-7867$

Référence électronique

Isabelle Pallot-Frossard, «De CHARISMA à IPERION CH et E-RIHS : vers une infrastructure européenne de recherche pour les sciences du patrimoine », Technè [En ligne], 43 | 2016, mis en ligne le 19 décembre 2019, consulté le 25 juillet 2020. URL : http://journals.openedition.org/techne/639 ; DOI : https://doi.org/10.4000/techne.639

\section{(c) $($ ) $\odot \odot$}

La revue Technè. La science au service de l'histoire de l'art et de la préservation des biens culturels est mise à disposition selon les termes de la Licence Creative Commons Attribution - Pas d'Utilisation Commerciale - Pas de Modification 4.0 International. 


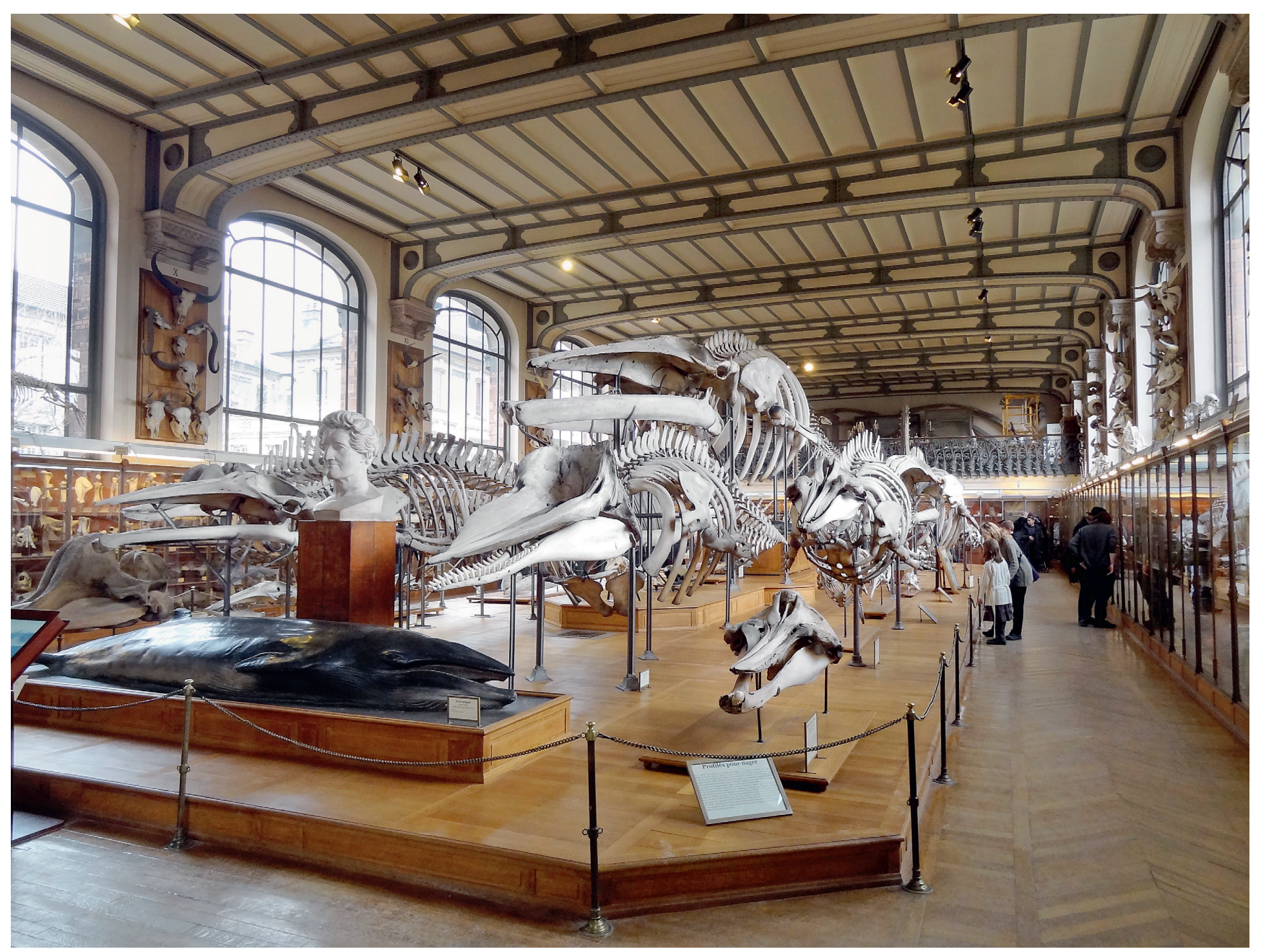

Fig. 1. Galerie de paléontologie, Museum national d'histoire naturelle, Paris.

The Paleontology Galery, National Museum of Natural History, Paris. @ I. Pallot-Frossard. 
Isabelle Pallot-Frossard

\section{De CHARISMA à IPERION CH et E-RIHS : vers une infrastructure européenne de recherche pour les sciences du patrimoine}

From CHARISMA to IPERION CH and E-RIHS: towards a European research infrastructure for heritage science

\begin{abstract}
Résumé. Ce bref article de synthèse traite des lignes de force du projet européen IPERION CH (2015-2019), qui fait suite aux projets LabS TECH, Eu-ARTECH et CHARISMA, ainsi que de la création d'une structure pérenne dédiée au développement de la recherche sur les sciences du patrimoine, dénommée E-RIHS. Inscrite, après sélection par le Forum ESFRI, sur la feuille de route des grandes infrastructures de recherche par la Commission européenne, celle-ci verra le jour en 2021 et élargira le champ d'investigation du patrimoine culturel et naturel aux collections d'histoire naturelle.

Mots-clés. Accès transnational, patrimoine culturel, collections d'histoire naturelle.
\end{abstract}

\begin{abstract}
This short paper describes the key elements of the European project IPERION CH (2015-19), which is the sequel to the Labs TECH, Eu-ARTECH and CHARISMA projects. It also outlines the creation of a long-term programme called E-RIHS (the European Research Infrastructure for Heritage Science). Listed on the ESFRI (European Strategy Forum on Research Infrastructures) Forum Roadmap, it will see the day in 2021 and will widen the field of research to natural history collections.

Keywords. Transnational access, cultural heritage, natural history collections.
\end{abstract}

Afin de maintenir le réseau très structuré établi grâce aux projets Labs TECH, Eu-ARTECH et CHARISMA, un quatrième projet, intitulé IPERION CH, a été monté, toujours par l'Italie $^{1}$, et a démarré en mai 2015 pour une durée de quatre ans. Ce projet rassemble aujourd'hui 24 partenaires représentant 12 États membres, auxquels s'ajoutent les États-Unis à travers le Getty Conservation Institute. Les partenaires français sont le CNRS (C2RMF, CRC ${ }^{2}$, IPANEMA ${ }^{3}$ ), SOLEIL et l'INRIA, représentant le consortium DARIAH (Digital Research Infrastructure for the Arts and Humanities). Ce projet, fondé sur les trois activités intrinsèques aux infrastructures, accès transnational, recherche associée et mise en réseau, voit se développer de manière importante les travaux de recherche, non pas seulement sur le développement instrumental, mais aussi sur les méthodes de conservation et de restauration et sur l'évaluation de leur efficacité, de leur innocuité pour la matière ancienne et de leur durabilité. C'est ainsi que vont être lancées des études sur le nettoyage des peintures, sur la protection des objets métalliques, sur la conservation des matériaux pierreux, ou sur l'impact des analyses par faisceau d'ions et rayons X sur la matière ancienne. Dans le domaine des outils disponibles, la plateforme mobile MOLAB s'est ouverte à de nouvelles techniques portables, telles que la Résonance magnétique nucléaire portable ou l'imagerie Térahertz, pour la visualisation et la caractérisation de couches superposées, développées dans le cadre du projet Charisma,
To maintain the highly structured network established through the Labs TECH, Eu-ARTECH and CHARISMA projects, a fourth project, entitled IPERION CH was prepared, coordinated as always by Italy ${ }^{8}$. It started in May 2015 for a period of four years. The project now brings together 24 partners from 12 Member States, plus the United States through the Getty Conservation Institute. The French partners are the CNRS (C2RMF, CRC ${ }^{9}$, IPANEMA ${ }^{10}$ ), the SOLEIL synchrotron and the INRIA, representing the DARIAH consortium (Digital Research Infrastructure for the Arts and Humanities). This project is based on the three activities intrinsic to Integrated Infrastructures: transnational access, joint research and networking. The project significantly develops research activities in the area not only of instrumental development, but also of conservation and restoration methods and the assessment of their efficiency, their harmlessness for ancient materials and their durability. Thus, studies will be launched on the cleaning of paintings, the protection of metal objects, the consolidation of stone, or the impact of ion beam and X-ray analysis on ancient materials. In the area of available tools, the MOLAB mobile platform adds new portable technologies such as portable nuclear magnetic resonance or terahertz imaging to visualize and characterize underlaying layers, two technologies developed during the Charisma project, or stimulated infrared thermography for the diagnosis of the state of conservation of wall paintings. The MOLAB mobile

Isabelle Pallot-Frossard, Conservateur général du patrimoine, directeur du Centre de recherche et de restauration des musées de France (isabelle.pallot-frossard@culture.gouv.fr). 
ou encore la thermographie infrarouge stimulée, pour le diagnostic de l'état de conservation de peintures murales, avec une implication renforcée des équipes françaises du C2RMF, du Laboratoire de recherche des monuments historiques et du Centre de recherche sur la conservation des collections.

Le développement instrumental ouvre de nouvelles voies de caractérisation des matériaux, comme la spectrométrie de masse portable, les analyses micro-destructives couplant différentes techniques laser comme la spectroscopie sur plasma induit par laser couplée à la spectroscopie Raman, permettant d'associer les analyses élémentaires et structurales, l'interférométrie holographique couplée à la thermographie infrarouge pour le diagnostic de défauts de surface des œuvres monumentales, ou encore la microscopie multiphotonique.

Au sein de ce projet, une activité spécifique est dédiée à la réflexion sur la création d'une infrastructure européenne pérenne, qui stabiliserait le réseau et les échanges scientifiques établis entre les partenaires, au-delà des projets successifs, dont les financements ne sont jamais certains. En parallèle, un projet d'infrastructure pérenne sur les sciences du patrimoine, intitulé E-RIHS (European research infrastructure for heritage science), a été déposé auprès du Forum stratégique européen pour les grandes infrastructures de recherche (ESFRI) ${ }^{4}$ afin d'être, à l'issue d'un processus de sélection très strict, inscrit sur la feuille de route européenne des futures infrastructures. Ce Forum a pour objectif de coordonner les initiatives nationales et de sélectionner des thèmes prioritaires de l'Europe pour les investissements lourds qu'elle devra consentir dans les années à venir. Le projet E-RIHS élargit le champ d'application d'IPERION CH en intégrant le patrimoine des collections d'histoire naturelle et vise des communautés scientifiques plus larges, comme celles de l'archéologie, de la paléoanthropologie ou de la paléontologie (fig. 1). Son intitulé qui porte sur les «sciences du patrimoine », implique une acception très large du concept, qui va bien au-delà des sciences de la conservation, qui irriguaient les projets précédents.

Au niveau national, les États membres, eux aussi, établissent une feuille de route régulièrement mise à jour, en coordination avec la stratégie européenne. C'est dans ce cadre que plusieurs pays partenaires d'IPERION CH ont, de leur côté, créé des plateformes nationales sur le thème du patrimoine. Ainsi ont été établies, ou sont en voie de l'être, les plateformes italienne, grecque, portugaise et hongroise. La France, elle aussi, est entrée dans cette dynamique et a déposé auprès du ministère chargé de la Recherche un projet de « nœud » français, en partie fondé sur le partenariat solide établi dans le cadre du LabEx PATRIMA (le C2RMF avec AGLAE, le synchrotron SOLEIL, la plateforme mobile de Patrimex gérée par le LRMH), mais incluant de nouvelles institutions à même de mettre à disposition des chercheurs français et européens de l'instrumentation scientifique de pointe, comme le Museum national d'histoire naturelle, la plateforme nationale de datation par le Carbone 14 Artémis (fig. 2), ou les outils laser développés par l'université de Cergy-Pontoise ${ }^{5}$. Ce projet a été accepté et platform also sees a greater involvement of French teams from the C2RMF, the Research Laboratory on Historic Monuments (LRMH) and Center for Research on the Preservation of Collections (CRCC).

Instrumental development opens new avenues for materials characterization, such as portable mass spectrometry, micro-destructive analyses coupling different laser techniques such as laser-induced breakdown spectroscopy coupled with Raman spectroscopy, thus combining elemental and structural analyses, holographic interferometry coupled with infrared thermography for the diagnosis of surface defects on monumental works, or multiphoton microscopy.

In this project, an activity is specifically dedicated to working on the creation of a sustainable European infrastructure which would stabilize the network and scientific exchanges already established between the partners beyond successive projects which funding is never guaranteed. In parallel, a sustainable infrastructure project for heritage science entitled E-RIHS (European research infrastructure for heritage science) has been submitted to the European strategy Forum on major research infrastructures (ESFRI) ${ }^{11}$ to be, after a very strict selection process, included in the European roadmap of future infrastructures. This Forum aims to coordinate national initiatives and to select Europe's priority themes for large investments that will be made in the coming years. The E-RIHS project expands the scope of IPERION CH by integrating natural heritage objects from natural history collections and seeks to reach wider scientific communities, like those of archeology, paleoanthropology or paleontology (fig. 1). The title of the project refers to "heritage science" and implies a very broad interpretation of the concept which goes beyond conservation science which irrigated the previous projects.

At a national level, Member States also establish regularly updated roadmaps in coordination with the European strategy. It is in this context that several countries partners of IPERION $\mathrm{CH}$ have, for their part, created national platforms related to cultural heritage. Thus, the Italian, Greek, Portuguese and Hungarian platforms have been or are in the process of being established. France is also joining the momentum and has submitted the project of a French "node" to the Ministry of Research, based partly on the strong partnership established within the PATRIMA LabEx (C2RMF with AGLAE, SOLEIL synchrotron, the PATRIMEX mobile platform managed by the LRMH), but including also new institutions which are able to provide advanced scientific instrumentation to French and European scientists, such as the National museum of natural history, the Artemis national Carbon 14 (fig. 2) dating platform, or laser tools developed by the University of CergyPontoise $^{12}$. This project was accepted and put in March on the new French roadmap ${ }^{13}$.

The inclusion of the E-RIHS project in the European Roadmap for Research Infrastructures has also been confirmed by the ESFRI Forum. It is the only project, with its highly interdisciplinary nature, accepted in the humanities and social sciences field, among only 6 new projects relating 
publié en mars dernier sur la nouvelle feuille de route française ${ }^{6}$.

Le projet E-RIHS, vient d'être également validé par le Forum ESFRI pour être inscrit sur la feuille de route européenne des infrastructures de recherche, seul projet accepté, avec son caractère éminemment interdisciplinaire, dans le domaine des sciences humaines et sociales, parmi 6 nouveaux projets seulement, avec de grands instruments comme de gigantesques télescopes à neutrinos ou rayons gamma, ou encore des infrastructures biomédicales d'envergure ${ }^{7}$. Cette inscription au niveau national comme au niveau européen est un signe fort de reconnaissance de la spécificité et de l'importance de la discipline des sciences du patrimoine. Ce projet doit aboutir dans les dix ans à la mise en place d'un organisme européen structuré, que les États membres s'engagent à soutenir sur la longue durée, au minimum cinq ans, les statuts étant conçus pour être valables une vingtaine d'années. Cet organisme pérenne doit permettre de développer la recherche et les interactions interdisciplinaires autour de la connaissance du patrimoine matériel, en facilitant l'accès aux grands instruments et aux technologies de pointe, en favorisant l'interopérabilité et la mise en commun de données, mais aussi en stimulant les échanges de bonnes pratiques, dans un domaine devenu très fédérateur en Europe.

Fig. 2. Artemis, spectromètre de masse par accélérateur, laboratoire de mesure par le carbone 14, plateforme nationale de datation, Saclay. Artemis, the Accelerator-based Mass Spectrometer (AMS) at the Laboratory of Carbon 14 Measurement, National Dating Platform, Saclay, France. (C) CEA/P. Stroppa. to large instruments, such as gigantic neutrinos or gamma rays telescopes, or large-scale biomedical infrastructures ${ }^{14}$. These listings at a national level as well as at an european level are a strong acknowledgement of the specificity and significance of the heritage science field. Within ten years, this project should lead to the establishment of a structured European organization that the Member States are committed to support in the long term, at least five years, the statutes being designed to be valid about twenty years. This permanent organization must enable to develop research and interdisciplinary interactions around tangible heritage knowledge, facilitating access to large instruments and advanced technologies, promoting interoperability and the sharing of data, but also stimulating the exchange of good practices in a field that has become very unifying in Europe.

(Traduction en anglais : Elsa Bourguignon.)

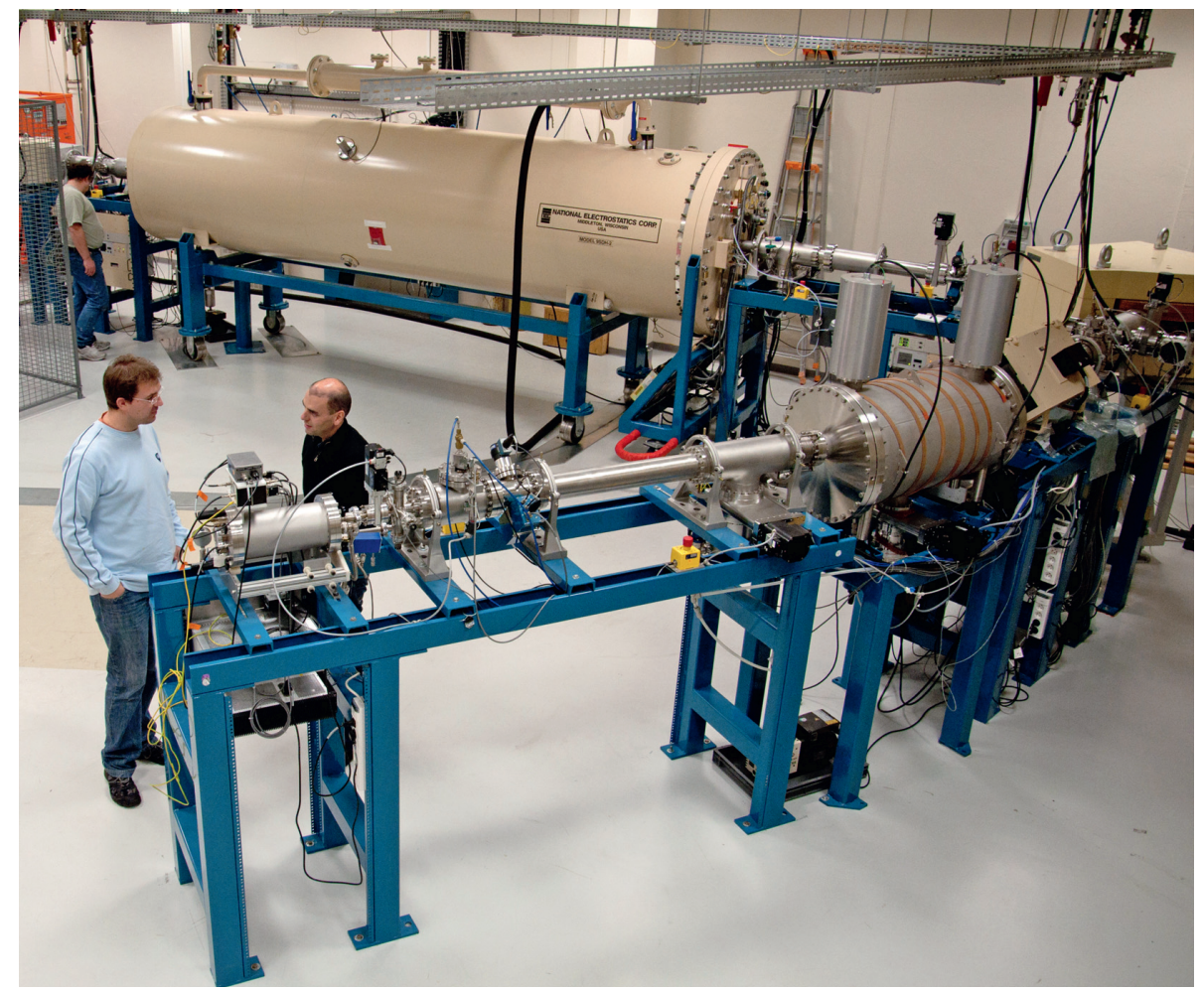

Notes

1. Par Luca Pezzati du CNR-INOA à Florence.

2. Centre de recherche sur la conservation des collections, USR 3224

3. IPANEMA est une unité mixte CNRS/ministère de la Culture et de la Communication/Université de Versailles Saint-Quentin-en-Yvelines (USR 3461).

4. http://ec.europa.eu/research/ infrastructures/index_en.cfm?pg=esfri
5. http://www.erihs.fr/

6. http://www.enseignementsuprecherche.gouv.fr/pid25384/strategienationale-des-infrastructures-de-recherche. html

7._http://ec.europa.eu/research/ infrastructures/index_en.cfm?pg=esfriroadmap

8. By Luca Pezzati from CNR-INOA in Florence.

9. Center for Research in Conservation, USR 3224
10. IPANEMA is a mixed research unit CNRS/Ministry of Culture and Communication/ University of Versailles Saint-Quentin-en-Yvelines (USR 3461).

11. http://ec.europa.eu/research/ infrastructures/index_en.cfm? ?pg $=$ esfri

12. http://www.erihs.fr/

13. http://www.enseignementsup-recherche gouv.fr/pid25384/strategie-nationale-desinfrastructures-de-recherche.html

14. http://ec.europa.eu/research/ infrastructures/index_en.cfm? pg=esfri-roadmap 